\title{
Perancangan Program Aplikasi Penjualan Food and Beverages pada Dawiels Café Bandar Lampung dengan Menggunakan Bahasa Pemrograman Visual Basic 6.0
}

\author{
Maria Shusanti F \\ Program Studi Teknik Informatika \\ Fakultas Ilmu Komputer \\ Universitas Bandar Lampung
}

Jln. Z.A. Pagar Alam No.26 Labuhan Ratu Bandar Lampung 35142

Telp. (0721) 701463, (0721) 701979 Fax. (0721) 701467 Web. www.ubl.ac.id

\begin{abstract}
ABSTRAK
Food and Beverages pada cafe Dawiels adalah restoran bernuansakan klasik dengan memberikan kenyamanan, kenikmatan dan tempat bersantai bersama teman dan keluarga. Cafe Dawiels terletak di pusat kota Bandar Lampung di Jalan Kartini No.41. Food and Beverages pada cafe Dawiels menawarkan berbagai makanan dan minuman cepat saji khas Cafe Dawiels seperti, Chicken Drum Steak (CDS), Chicken Steak, Macaroni Scutell dan lain-lain dan berbagai minuman seperti Greenday, Orange Juice, Hot Cappucino dan lainlain. Dengan harga yang terjangkau dan relatif murah, disertai dengan live musik untuk kenyamanan konsumen.

Selama ini pengolahan data penjualan food and Beverages pada Cafe Dawiels Bandar Lampung masih menggunakan sistem manual, yang berarti dalam pencatatan transaksi penjualan masih berupa kertas-kertas yaitu kertas pesanan, nota penjualan dan lain-lain. Hal ini membuat pengolahan data kurang efektif dan banyak kekurangan untuk mendukung manajemen. Untuk hal tersebutlah penulis berkeinginan untuk membuat sistem pengolahan data dengan menggunakan komputerisasi yaitu dengan program visual basic 6.0, sehingga sistem penjualan dapat berjalan dengan baik dan tercatat dengan rapi, sekaligus penulis mengenalkan penggunaan aplikasi komputer.

Adapun yang menjadi permasalahan dalam penulisan ini adalah"Bagaimana perancangan program aplikasi penjualan Food and Beverage pada Cafe Dawiels Bandar Lampung menggunakan Bahasa Pemograman Visual Basic 6.0”.

Tujuan penyusunan laporan akhir studi ini adalah untuk menjabarkan, menggambarkan dan melaporkan hasil dari pelaksanaan penyusunan laporan akhir studi serta untuk memberikan pandangan dan pengalaman langsung di dalam dunia kerja, sehingga mahasiswa dapat mengintegrasikan teori dan praktek yang diperoleh dibangku perkuliahan dengan kenyataan yang ada dilapangan.
\end{abstract}




\section{PENDAHULUAN}

Pada masa ini, teknologi informasi berkembang sedemikian pesatnya, didukung oleh peranan komputer dalam pengolahan data maupun informasi. Hal ini dikarenakan karakteristik manusia yang mudah jenuh dan lambat dalam pengolahan data dalam jumlah yang sangat besar, sehingga komputer sangat dibutuhkan untuk membantu manusia melakukan pengolahan, perhitungan, sampai analisa terhadap data dan informasi.

Informasi merupakan darah dan elemen penting dalam menjaga kelangsungan hidup suatu organisasi. Hal ini menunjukkan betapa pentingnya informasi bagi suatu organisasi, termasuk perusahaan. Suatu perusahaan yang memiliki sistem informasi yang baik akan sangat membantu pihak manajemen dalam pengambilan keputusan, dan menentukan strategi bisnis sesuai dengan bidang usahanya. Hal ini akan meningkatkan eksistensinya dalam persaingan dunia bisnis.

Saat ini, tidak sedikit perusahaan yang masih menggunakan sistem manual dalam pengolahan data transaksi, sampai pembuatan laporan kepada pihak manajemennya. Ini dikarenakan mereka kurang menyadari arti pentingnya informasi bagi perusahaannya. Mereka berfikir walaupun tanpa sistem informasi terkomputerisasi, usahanya masih dapat berlangsung. Namun dalam pengolahan data transaksinya, sering terjadi kesalahan pemasukan data yang disebabkan oleh faktor manusia (human error), padahal laporan yang akan dibuat bergantung dari hasil pemasukan data tersebut. Dampak dari kesalahan ini dapat mengakibatkan pengambilan keputusan yang kurang tepat bagi perusahaan itu.

Food and Beverages pada Café Dawiels adalah sebuah restoran bernuansakan klasik yang terletak pada Jalan Kartini No.41 Bandar Lampung. Food and Beverages pada Café Dawiels menawarkan berbagai makanan dan minuman cepat saji khas pemilik Ibu Samira Kamal seperti roti bakar, chicken nugget, spagetti dan berbagai jenis minuman seperti hot coffee, hot capuccino dan minuman lainya. Dengan harga yang terjangkau dan relatif murah, disertai dengan live musik untuk kenyamanan kosumen.

Dalam pengolahan data penjualan Food and Beverages pada Café Dawiels Bandar Lampung masih menggunakan sistem manual, yang berarti dalam pencatatan data transaksi penjualan masih berupa kertas-kertas yaitu kertas pesanan, nota penjualan dan lain-lain. Hal ini membuat pengolahan data kurang efektif untuk mendukung keputusan manajemen.

\subsection{Identifikasi Masalah}

Sistem yang berjalan dalam penjualan Food and Beverages pada Café Dawiels Bandar Lampung selama ini ternyata masih banyak menimbulkan masalah-masalah. Berikut ini disajikan masalahmasalah yang sering timbul :

1. Kesalahan pencatatan transaksi.

2. Laporan yang kurang akurat.

3. Terjadinya kehilangan data transaksi tertentu.

4. Sulitnya melakukan pencarian data transaksi. Dari permasalahan-permasalahan tersebut, penulis mengidentifikasi hal-hal penyebab timbulnya masalah-masalah tersebut yaitu :

1. Pencatatan data transaksi yang masih menggunakan cara manual ternyata menimbulkan kesalahan-kesalahan umum yang terjadi akibat faktor manusia (human error), seperti kesalahan pencatatan harga, jumlah barang masuk, dan jumlah barang keluar.

2. Pembuatan laporan yang didasarkan dari pemasukan data yang salah menghasilkan laporan penjualan yang tidak akurat kepada pihak manajemen.

3. Terjadi kehilangan data transaksi tertentu baik disengaja ataupun tidak disengaja oleh pihak-pihak tertentu, demi kepentingan pribadi atau kepentingan golongan tertentu.

4. Penyimpanan data transaksi dalam bentuk arsip berupa kertas-kertas dirasakan tidak efektif untuk pencarian kembali.

Sehingga untuk menyelesaikan masalah-masalah diatas, diperlukan sebuah sistem yang mampu menangani dengan baik mulai dari proses penginputan data transaksi, sampai proses pembuatan laporan kepada pimpinan. Sistem 
komputerisasi dirasakan perlu untuk diterapkan dalam sistem penjualan Food and Beverages pada Café Dawiels Bandar Lampung. Diharapkan dengan sistem terkomputerisasi, masalah - masalah tersebut dapat diatasi.

\subsection{Batasan Masalah}

Sistem yang ada dalam Food and Beverages pada Café Dawiels Bandar Lampung cukup kompleks, meliputi sistem penjualan makanan dan minuman, sistem laporan penjualan, sistem penggajian karyawan, sistem pemesanan barang kepada pemasok, dan masih terdapat beberapa sistem lainnya. Oleh karena itu penulis merasa perlu untuk membatasi penelitian terhadap salah satu sistem yang terdapat dalam Food and Beverages pada Café Dawiels Bandar Lampung yaitu sistem penjualan makanan dan minuman. Analisis dan perancangan program aplikasi yang akan dilakukan meliputi pencatatan data transaksi penjualan makanan dan minuman sampai pembuatan laporan yang akurat kepada pihak manajemen.

\subsection{Tujuan Penelitian}

Maksud penulis dalam membuat penulisan ilmiah ini adalah :

1. Menunjukkan kesalahan yang terjadi dari pencatatan transaksi secara manual yang disebabkan oleh faktor human error dapat menimbulkan kesalahan dalam penentuan kebijakan yang dilakukan pihak manajemen.

2. Mengatasi permasalahan-permasalahan yang terjadi sehingga akhirnya sistem dapat menjadi lebih efisien.

\subsection{Manfaat Penelitian}

Manfaat penulis dalam membuat penulisan ilmiah ini adalah :

1. Sebagai salah salah satu syarat kelulusan dalam menempuh program sarjana komputer S1 Fakultas Ilmu Komputer program studi Teknik Informatika Universitas Bandar Lampung.

2. Sebagai bahan penelitian yang dibuat penulis sebagai syarat kelulusan sarjana $\mathrm{S} 1 \mathrm{di}$ Fakultas Ilmu Komputer Universitas Bandar Lampung.

3. Memperkenalkan sebuah program aplikasi penjualan yang dibuat oleh penulis dengan menggunakan software Microsoft Visual Basic 6.0.

\section{LANDASAN TEORI 2.1 Konsep Dasar Sistem Informasi}

Sistem adalah sekelompok elemen yang terintegrasi dengan maksud yang sama untuk mencapai suatu tujuan ( Raymod McLeod, $2001: 11$ )

Sumber daya mengalir dari elemen input, melalui transformasi, lalu menghasilkan elemen output. Suatu mekanisme pengendalian memantau proses transformasi untuk meyakinkan bahwa sistem tersebut memenuhi tujuannya. Mekanisme pengendalian ini dihubungkan pada arus sumber daya dengan memakai suatu lingkaran umpan balik (feedback loop) yang mendapatkan informasi dari output sistem dan menyediakan informasi bagi mekanisme pengendalian. Mekanisme pengendalian membandingkan sinyal-sinyal umpan balik ke sasaran dan mengarahkan sinyal pada elemen input jika sistem operasi memang perlu diubah ( Raymod McLeod, 2001:12 ).

Kita juga mengenal istilah subsistem dan supersistem. Subsistem sebenarnya adalah sistem didalam suatu sistem, dan supersistem adalah bagian sistem yang lebih besar ( Raymod McLeod, 2001 : 13 ). Contohnya jika pemerintahan Lampung adalah suatu sistem, maka pemerintahan Bandar Lampung adalah subsistemnya, dan pemerintahan Indonesia adalah supersistemnya.

\subsubsection{Konsep Data dan Informasi}

Seringkali pengertian data dan informasi sering disamakan, padahal secara konseptual data dan informasi mempunyai arti yang berbeda. Data terdiri dari fakta-fakta, angka-angka, atau simbolsimbol dan relatif bersifat objektif. Sedangkan informasi merupakan hasil pemrosesan dari data dan bersifat subjektif

( Raymod McLeod, 2001 : 15 ).

\subsection{Definisi Sistem Informasi}

Menurut Robert A. Szymanski (1995), sistem informasi adalah sekumpulan fungsi yang bekerja secara bersama-sama dalam mengelola pengumpulan, penyimpanan, pemrosesan, serta pendistribusian aplikasi. Definisi ini memberikan pengertian yang sangat luas mengenai sistem informasi. Berdasarkan pengertian diatas, maka 
semua pekerjaan yang berkaitan dengan pengolahan, penyimpanan, pengaturan, dan pendistribusian informasi baik secara manual maupun terkomputerisasi dikatakan bagian dari sistem informasi ( Dadan Umar Daihani, 2001 : 1 ).

Dari pembahasan tersebut, terlihat bahwa secara umum fungsi utama sistem informasi ada tiga yaitu

a. Mengambil data ( data capturing / input ),

b. Mengolah, mentransformasi, dan mengkonversi data menjadi informasi,

c. Mendistribusikan informasi (reporting / disseminating) kepada para pemakai atau user.

( Dadan Umar Daihani, 2001 : 6 ).

\subsection{Tahap-tahap Perancangan Program}

Untuk membuat atau menyusun suatu program yang besar dan kompleks, pemrograman membutuhkan beberapa tahapan-tahapan yang sistematis dan terpadu, yaitu :

\subsubsection{Definisi Masalah}

Pendefinisian masalah untuk mendapatkan pemahaman tentang permasalahan yang ada, sehingga akan diperoleh asumsi-asumsi yang benar untuk dapat memecahkan permasalahan ( Indra Yatini B : 2001: 6 ).

\subsubsection{Analisis Kebutuhan}

Analisis kebutuhan merupakan aktifitas komunikasi yang paling intensif dan merupakan tugas utama yaitu pengenalan masalah, evaluasi masalah serta sintesis yang merupakan tugas yang harus dikuasai dengan mahir untuk mendapatkan informasi yang dibutuhkan.

\subsubsection{Desain Algoritma}

Desain algoritma dibuat sama dengan menuliskan langkah-langkah dalam pemecahan masalah yang ada, karena algoritma dibuat dengan tujuan untuk menyelesikan sutu permasalahan. Algoritma yang dibuat tidak langsung jadi dan harus dikaji terusmenerus, sehingga akan diperoleh algoritma yang paling relevan, karena harus memiliki kebenaran secara logika sebelum siap untuk diimplementasikan dalam bentuk program.

Fase dari desain algoritma terlengkap bila telah mempumyai suatu depenelitian penuh, dan bila kajian yang telah dilakukan tidak lagi menyingkap permasalahan, berat telah siap untuk melngkah dengan pengkodean ( Indra Yatini B : $2001: 7,8$ ).

\subsubsection{Pengkodean}

Pengkodean adalah kemudahan yang didapat pemeliharaan maupun dalam mengerti kode sumber yang telah dibuat. Pengkodean menekankan kepada kesederhanaan dan kejelasan pengkodean meliputi . ( Indra Yatini B : $2001: 8$ )

a. Dokumentasi kode

Dokumentasi kode atau dokumentasi program sumber dimulai dengan pemilihan identifier ( variable dan label ), kemudian dilanjutkan dengan penyusunan komentar serta penggambaran dari organisasi program yang telah dibuat. Pemilihan nama pada identifier yang mudah dimengerti merupakan bagian yang paling kritis, karena banyak bahasa pemrograman yang mempunyai keterbatasan pada saat pemberian nama untuk variabel.

b. Deklarasi data

Deklarasi data ditentukan apabila kode telah dibuat dan terdapat sejumlah petunjuk yang dapat digunakan untuk membuat data mudah dimengerti dan mudah pemeliharaannya.

c. Penyusunan perintah

Penyusunan perintah merupakan bagian dari langkah pengkodean, karena banyak dari bahasa pemrograman yang mengijinkan lebih dari satu perintah dalam satu baris.

\subsubsection{Bahasa Pemrograman}

Di dalam pengkodean adalah menterjemahkan desain ke dalam bahasa pemrograman aktual, sebagian besar kesulitan telah harus terpecahkan pada tahap sebelumnya, sehingga pemrogram bebas untuk mencurahkan perhatian penuh untuk pembuatan program.Bahasa pemrograman merupakan kendaraan yang digunakan untuk berkomunikasi antara manusia dengan mesin komputer. Karakteristik dari bahasa pemrograman mempunyai pengaruh yang penting dari kualitas komunikasi, begitu juga kerekayasaan bahasa pemrograman mempunyai pengaruh yang penting terhadap berhasil tidaknya suatu program yang akan di buat. Pemilihan bahasa pemrograman, yang merupakan hal yang sangat penting bagi pemrogram untuk mulai membuat program. Fungsi dari bahasa pemrograman adalah sebagai media 
untuk membuat program dan memahami serta sebagai alat komunikasi antara pemrogram dan komputer. Pemilihan bahasa pemrograman harus tepat dan sesuai dengan permasalahan yang ada. Beberapa kriteria yang digunakan untuk mengevaluasi pemilihan bahasa pemrograman yaitu

1. Bidang aplikasi yang sedang dikerjakan

2. Kekomplekskan algoritma dan perhitungan

3. Lingkungan dimana perangkat lunak akan diterapkan

4. Pengetahuan staf akan bahasa pemrograman

5. Ketersediaan kompiler yang baik. (Indra Yatini B : $2001: 9$ )

\subsubsection{Testing dan Debugging}

Testing adalah menguji program sampai dipenuhi bebas error lewat bermacam-macam kondisi atau dengan input yang hasilnya dapat diprediksi. Testing tidak dapat secara absolut bisa yakin bahwa program adalah benar.

Debugging adalah mengoreksi error yang terdeteksi meliputi menetapkan lokasi kode yang error dan mengoreksinya.

Debugging adalah penghilangan semua kesalahan yang ditemukan oleh pengujian dan bisa sangat memakan waktu, terutama pada saat pembuatan program melakukan kecerobohan desain dan pengkodean.

Kesulitan utama pada debugging adalah untuk melacak kesalahan, yaitu mencari pernyataan atau bagoan dari suatu program dimana kesalahan terjadi. Begitu letak kesalahan diketahui, sebuah pembacaan mengenai bagian yang salah tersebut biasanya akan mengungkap sumber dari kesalahan yang ada. ( Indra Yatini B : 2001 : 7,130,133 )

\subsubsection{Dokumentasi}

Dokumentasi merupakan informasi dan gambaran tambahan yang sangat membantu untuk memahami sebuah kode yang diberikan. Tujuannya adalah untuk menjadi pedoman dan penjelasan bagi para pemakai. Dokumentasi dapat dibedakan, yaitu dokumentasi internal dan dokumentasi eksternal. Dokumentasi internal sebenarnya merupakan bagian kode hanya sebuah eksplansi dari berbagai aspek lewat komentar. Dokumentasi eksternal adalah dalam bentuk manual dan catatan-catatan penting tentang program. Dokumentasi internal dan eksternal harus konsisten satu sama lain dengan kode. ( Indra Yatini B : $2001: 10$ )

\subsubsection{Pemeliharaan}

Pemeliharaan perangkat lunak digunakan untuk menjabarkan aktivitas dari analisis sistem pada saat perangkat lunak telah dipergunakan oleh pemakai. Aktivitas yang terjadi pada fase pemeliharaan antara lain :

a. Penambahan atau peningkatan atau juga perbaikan untuk perangkat.

b. Adaptasi perangkat lunak dengan lingkungan mesin yang baru.

c. Perbaikan permasalahan yang timbul. ( Indra Yatini B : $2001: 11,12$ )

\subsection{Alat Analisis Sistem Informasi}

Dalam menganalisis suatu system informasi, system analyst memerlukan beberapa tool / alat yang dapat membantunya untuk menggambarkan sistem lebih jelas dan tepat. Berikut ini akan dijelaskan mengenai alat-alat analisis yang digunakan oleh system analyst meliputi Data Flow Diagram (DFD), Entity Relationship Diagram (ERD), dan Data Dictionary atau Kamus Data.

\subsubsection{Data Flow Diagram ( DFD )}

Data Flow Diagram atau Diagram Arus Data merupakan salah satu tool yang paling penting bagi seorang system analyst. Penggunaan Diagram Arus Data sebagai modelling tool dipopulerkan oleh Tom DeMarco (1978) dan Gane \& Sarson (1979) dengan menggunakan pendekatan metode analisis sistem terstruktur.

Data Flow Diagram adalah suatu gambaran grafis dari suatu sistem yang menggunakan sejumlah bentuk-bentuk simbol untuk menggambarkan bagaimana data mengalir melalui suatu proses yang berkaitan (Raymod McLeod, 2001 : 316).

\section{Perancangan dan Implementasi 4.2.8 Perancangan Database}

Nama database : dbpenjualan

Tabel-table yang akan digunakan untuk aplikasi ini adalah :

\section{a. Tabel Karyawan}


Nama Tabel: tbl_karyawan

\begin{tabular}{|l|l|l|}
\hline \multicolumn{1}{|c|}{ Nama Field } & $\begin{array}{c}\text { Jenis } \\
\text { Field }\end{array}$ & $\begin{array}{c}\text { Panjang } \\
\text { Field }\end{array}$ \\
\hline id_karyawan & Text & 5 \\
\hline nama_karyawan & Text & 30 \\
\hline Jabatan & Text & 20 \\
\hline
\end{tabular}

\section{b. Tabel Menu}

\begin{tabular}{|l|l|l|}
\multicolumn{1}{|c}{ Nama Tabel } & \multicolumn{2}{c|}{ :tbl_menu } \\
& $\begin{array}{r}\text { Jenis } \\
\text { Field }\end{array}$ & $\begin{array}{c}\text { Panj } \\
\text { ang } \\
\text { Fiel } \\
\text { d }\end{array}$ \\
\hline id_menu & Text & 4 \\
\hline nama_menu & Text & 50 \\
\hline harga_menu & Currency & 8 \\
\hline jml_persediaan & Integer & 2 \\
\hline
\end{tabular}

\section{c. Tabel Order Pesanan}

Nama Tabel

\begin{tabular}{|l|l|l|}
\hline Nama Field & \multicolumn{1}{|c|}{$\begin{array}{c}\text { Jenis } \\
\text { Field }\end{array}$} & $\begin{array}{c}\text { Panjang } \\
\text { Field }\end{array}$ \\
\hline id_penjualan & Text & 50 \\
\hline tanggal & date & - \\
\hline no_meja & Text & 50 \\
\hline total & Currency & 8 \\
\hline operator & Text & 30 \\
\hline Waiters & Text & 30 \\
\hline
\end{tabular}

\section{d. Tabel Order Rinci}

Nama Tabel

: TRincianOrder

\begin{tabular}{|l|l|l|}
\hline Nama Field & $\begin{array}{c}\text { Jenis } \\
\text { Field }\end{array}$ & $\begin{array}{c}\text { Panjang } \\
\text { Field }\end{array}$ \\
\hline id_penjualan & Text & 50 \\
\hline id_menu & Text & 10 \\
\hline nama_menu & Text & 50 \\
\hline harga_menu & Currency & 8 \\
\hline banyak & Integer & 2 \\
\hline Jumlah & Currency & 8 \\
\hline
\end{tabular}

\section{d. Tabel Transaksi Pembayaran}

Nama Tabel tpembayaran

\begin{tabular}{|l|l|l|}
\hline Nama Field & Jenis Field & \multicolumn{1}{|c|}{$\begin{array}{c}\text { Panjang } \\
\text { Field }\end{array}$} \\
\hline id_penjualan & Text & 50 \\
\hline tanggal & date & - \\
\hline no_meja & Text & 50 \\
\hline operator & Text & 30 \\
\hline Waiters & Text & 30 \\
\hline Total & Currency & 8 \\
\hline
\end{tabular}

\section{KESIMPILAN DAN SARAN}

\subsubsection{Kesimpulan}

Penulis menarik kesimpulan sebagai berikut:

a. Proses pencatatan transakasi penjualan Food and Beverages pada Dawiels Café Bandar Lampung masih menggunakan cara manual. Kesalahan akibat human error dalam pemasukan data transaksi sangat rentan terjadi.

b. Pembuatan laporan yang didasarkan dari pemasukan data yang salah menghasilkan laporan penjualan yang tidak akurat kepada pihak manajemen.

c. Terjadi kehilangan data transaksi tertentu baik disengaja ataupun tidak disengaja oleh pihakpihak tertentu, demi kepentingan pribadi atau kepentingan golongan tertentu.

d. Peralihan (switch over) perlu dilakukan oleh Dawiels Café Bandar Lampung, dari sistem non komputerisasi menjadi sistem terkomputerisasi.

\section{DAFTAR PUSTAKA}

1. Dadan Umar Daihani. Komputerisasi Pengambilan Keputusan. Penerbit PT. Gramedia Jakarta. Jakarta: 2001.

2. Fathansyah. Basis Data. Penerbit Informatika Bandung. Bandung: 1999.

3. H. M. Jogiyanto. Analisis dan Desain Sistem Informasi. Penerbit Andi Yogyakarta. Yogyakarta: 1992.

4. Raymond McLeod, Jr. Sistem Informasi Manajemen. Jilid Satu. Edisi Ketujuh. Penerbit PT. Prenhallindo. Jakarta: 1997. 
5. Wahana Komputer Semarang.

Pemrograman Visual Basic 6.0. Penerbit Andi Yogyakarta. Semarang: 2000. 
Explore - Jurnal Sistem Informasi dan Telematika ISSN 2087-2062 